\title{
A Comparative Approach to Fiscal Illusions: a Synthesis of the Conclusions from a Polish Study in Relation to New Ideas and Empirical Research in Selected Countries ${ }^{1}$
}

\author{
Beata Guziejewska (iD) https://orcid.org/0000-0002-0814-5066 \\ Ph.D., Associate Professor at the University of Lodz \\ Faculty of Economics and Sociology, Lodz, Poland \\ e-mail: beata.guziejewska@uni.lodz.pl
}

\begin{abstract}
This article examines fiscal illusions in public finance systems where decentralisation involving the introduction of an independent and autonomous component of local government funding brings new problems. It presents a synthesis of the findings from a Polish empirical study that set out to determine the types and extent of fiscal illusion among Polish councillors, focusing on the qualitative aspects of the phenomenon. It also compares the findings with other streams of research and new approaches to fiscal illusion. The purpose of the article is to systematise the knowledge of fiscal illusion based on selected empirical studies, to formulate proposals for practitioners and public decision-makers, and to highlight areas for future research to address. The article was prepared using a desk research approach and the author's own experiences and research perspective formed during the study of fiscal illusions. The findings presented in the article corroborate its main thesis that a local government funding system based on intergovernmental transfers contributes to the emergence and perpetuation of fiscal illusions.
\end{abstract}

Keywords: fiscal decentralisation, fiscal illusions, intergovernmental fiscal relations, local taxes

JEL: H70, H71, H77

1 Research project financed by Poland's National Science Center, under Grand Opus, Dec-2014/13/B/ HS4/00162, "The role of the system of financing local government in the creation and perpetuation of fiscal illusion. Complementarity of qualitative and quantitative methods". 


\section{Introduction}

Fiscal illusions have long been an interesting subject matter for economists, political scientists, management and administration scientists, sociologists, and psychologists. The term 'illusion' has psychological connotations and is interpreted as incomprehension, misperception, misinterpretation, or misjudgement about things, phenomena, or processes. An illusion is, therefore, a behavioural reaction that frequently arises when we are lying to ourselves or to other people, or as a form of self-defence against objective facts and circumstances.

Fiscal illusion is understood to follow from the incomprehension of public finance laws and mechanisms. It can affect politicians, public administration staff and public officials, as well as ordinary citizens (taxpayers, voters, and the beneficiaries of public funds). The classical literature on fiscal illusion was inspired by the new political economy and initially focused on the taxation problems (Oates 1972; 1998 pp. 65-82; Dollery and Worthington 1996, pp. 296-297; Buchanan 1997, pp. 158; Gemmell, Morrissey, and Pinar 2002, pp. 199-224). A well-known stream within public finance science which developed in Italy and is frequently referenced to in the literature emphasises the fundamental importance of the structure and nature of political institutions in the creation of fiscal illusions, whereas the Anglo-Saxon approach underscores the public authorities' inclination to hide the true costs of taxes (see: Guziejewska 2016a, pp. 58-61).

The progress in decentralisation processes observed in many countries in recent decades has increased interest in considering fiscal illusion in terms of local government finances and intergovernmental transfers (Oates 1979; Rosen 1999, p. 502; Mueller 2003, p. 221; Gordon 2004, p. 1776). Although local governments have fewer fiscal and legislative powers than the central government does, they do have some financial autonomy and independence, which leads to the emergence of sometimes complicated intergovernmental fiscal relations. The emergence of fiscal illusions is traditionally attributed mainly to incomplete information and unequal access to it, which are used by opportunistic politicians to maximise their self-interests and improve the odds of re-election. The appearance of new fiscal illusions in decentralised systems is believed to be caused by the complexity of intergovernmental fiscal relations, the central government devolving more and public services to local governments without providing them with access to efficient and adequate sources of funding (local taxes, etc.), and the complicated mechanisms governing intergovernmental transfers. As well as contributing to the emergence of illusions, fiscal decentralisation, especially one that is limited and incomplete, also gives rise to moral hazards and ineffective redistribution of public funds (Akin, Bulut-Cevik and Neyapti 2016, pp. 690-705). The macroeconomic studies on fiscal illusions consider it from the perspective of public debt and accrual accounting, which can lead to the development and amplify many fiscal illusions about public authorities' assets and liabilities (Irwin 2016, pp. 219-227). This leads to a question about whether fiscal decentralisation tightens fiscal discipline, 
thus becoming an element of soft budget restrictions, or rather relaxes it. It is believed that the emergence of fiscal illusions can be hindered or prevented by subjecting the public finance sector to institutional rules and principles, as well as by tax competition (Ahmad and Brosio, 2015, pp. 85-106).

A research project devoted to fiscal illusions carried out in Poland between 2015 and 2016 analysed and compared the qualitative and quantitative aspects of the phenomenon, concentrating on the qualitative factors that are frequently neglected in studies. Information for this study was collected during in-depth interviews and a questionnaire survey of councillors representing communities in the seven largest Polish cities. In the article, the main findings of the study are juxtaposed with new views, ideas, and the outcomes of empirical research into fiscal illusion. The article also systemises the existing knowledge of fiscal illusions based on selected empirical studies, formulates recommendations for practitioners and public decision-makers, and indicates areas for future research. It was prepared using a desk research approach and the author's own experiences and research perspective formed during the study of fiscal illusions among Polish councillors.

This article is a theoretical work. It consists of the introduction section, a synthesis of the results of the empirical qualitative study on fiscal illusions in Poland, an overview of some recently published empirical studies, ideas and perspectives, and the conclusions section.

\section{A synthesis of the findings of the Polish study, with a special focus on the results of in-depth interviews}

The problem of fiscal illusion among local governments is gaining in importance as more and more costly public services are devolved to lower levels of government without the distribution of adequate tax revenues. The general public in representative democracies do not need to understand the mechanisms of public life and public finances, which are quite frequently complicated, but those who represent them, including city councillors, can be rightly expected to have knowledge of them. The assumption was used as a starting point to study fiscal illusions among the councillors in several of the largest cities in Poland. The first phase of the study, intended as a pre-test, included a series of focused, in-depth interviews with ten councillors from the city of Łódź (qualitative research). The councillors' answers to open-ended questions were used to prepare detailed questionnaires, which were then distributed to councillors in the seven largest Polish cities (quantitative research). Both phases of the study led to similar conclusions (Guziejewska 2016b, pp. 483-489).

The questions asked during the in-depth interviews and the questionnaire survey concentrated on the special design of the local government funding system in Poland, with intergovernmental transfers as the primary source of funding for the subnational levels of government. Intergovernmental transfers should be understood as including 
not only general grants and specific grants but also local governments' shares of personal income tax (PIT) and corporate income tax (CIT; shared taxes) collected by the central government. It is notable that among Polish taxes, only the property tax is fiscally efficient. Therefore, the questions asked during both phases concerned the range of locally administered taxes in relation to fiscal autonomy and respondents' expectations as to other sources of local revenue (general and specific grants).

According to information gathered during the in-depth interviews, the main source of the councillors' fiscal illusions was their superficial knowledge of finances and budget management, as well as political factors. The study started with an assumption that because councillors have many regular and ad-hoc responsibilities, including financial ones, they would have a good general knowledge of the system through which local governments are funded. The assumption proved exaggerated. Councillors admitted that their financial interests were focused on matters vital for local residents but relatively unimportant in terms of the entire financing system. However, although limited, their general knowledge of the financing of the local governments' tasks was diverse and associated with their function on the council and its commissions.

An analysis of answers to the specific questions confirmed a high level of fiscal illusions among councillors. Many of them were for increasing the municipalities' shares of PIT and CIT, and the overwhelming majority opposed increases in municipal taxes, charges, and fees. The councillors were also strongly averse to making local revenues the main source of funding for the municipality. Some of the councillors who were against increasing resident taxation observed that municipalities needed more effective ways to collect amounts due to them.

The councillors had a problem answering the question about what systemic solutions might be effective in increasing municipalities' revenues. Most of them wanted intergovernmental transfers (the municipal shares of PIT, as well as general grants and specific grants) and the education component of the general grant to be increased. The need to stimulate the development of the local economy was also indicated. Generally, however, the councillors' primary concern was that the local tax burden not be increased, as if they did not understand that general grants are funded from taxes paid by all citizens in the country. The way they formulated their answers also betrayed an undertone of distrust in the government. In order to explain their aversion to changes, the councillors recalled cases when the government failed to respect the principle of adequacy. Nonetheless, many respondents found the existing local revenue system to be good and in no need of major changes.

While debt was indicated as one of the main problems haunting local budgets, the councillors had significantly different views on its causes and role. Some councillors blamed 'wasteful' investment projects; others argued that extensive investment efforts, although costly, were necessary to advance the city's development city. Also mentioned were the unique availability of EU funds and the need to make long-term efforts to improve the quality of life of the residents. The councillors had difficulty choosing between revenue increase and expenditure cuts as the way to reduce a budget deficit. Sev- 
eral of them dodged giving a clear answer by choosing both options. Those who chose the first measure were unable to indicate which revenues should be increased.

An indication of the high level of fiscal illusion among the councillors is that none of them wanted to increase the fiscal autonomy of local authorities. The dominant opinions were that making decisions was the responsibility of national, rather than local, politicians; they also revealed some reservations about increasing residents' local tax burden. Many councillors expected the municipal shares of national taxes and general and specific grants to be increased. Neither extremely demanding nor dogmatic attitudes that involved rejecting other people's standpoints were observed among the respondents. The real property ad valorem tax as a source of local revenue found several supporters, who explained their acceptance of it by referring to the paradoxes of the property management system in place. It was, nevertheless, an unusual finding, because the tax is widely criticised as very burdensome for taxpayers.

The quantitative part of the study, during which each respondent answered 12 questions on a 5-point Likert scale, provided yet more evidence of the high level of fiscal illusion among Polish councillors. The study was innovative, given that councillors are local politicians who are a very special and uncooperative sort of respondent (the questionnaire return rate was only 23\%). The statistical analysis of their answers and personal characteristics (e.g., the level of education or the number of terms on the council) did not show significant associations between them. The question about whether increasing intergovernmental transfers (general and specific grants) was the right way to boost municipal revenues was answered 'yes' or 'rather yes' by $68 \%$ of the councillors; $86 \%$ of them wanted the municipal share of PIT and CIT to be increased. Only $24 \%$ supported raises in local taxes and charges as a source of additional revenues for the municipality, whereas $72 \%$ rejected this possibility. In the opinion of $77 \%$ of the councillors, local governments in Poland should have more powers to decide on the rates of local taxes and charges ('yes' and 'rather 'yes'). Paradoxically, however, the councillors expressed their reluctance to raise local taxes during both parts of the study (qualitative and quantitative).

The councillors had knowledge of the residential property tax and did not think it was a major burden for the taxpayers; $75 \%$ of answers to the question about whether the tax was high and burdensome for the property owners were 'no' or 'somewhat no'. The introduction of the cadastral tax was opposed by most of the councillors, but $30 \%$ would support such a decision; a surprising finding given that the tax is deemed extremely controversial. Some light was shed on this inconsistency by the qualitative part of the study (the interviews) when the councillors who would accept the tax criticised the absurdities in property management caused by the property taxation system in place.

As for fiscal illusions associated with budget expenditures and budget deficit, their level was much lower among the councillors: 93\% believed that expenditure cuts were the right way to reduce excessive deficit. 
Table 1. A synthetic review of the results of in-depth interviews with the Łódź councillors

\begin{tabular}{|c|c|c|c|c|}
\hline Specification & $\begin{array}{c}\text { Basic } \\
\text { (introductory) } \\
\text { answer }\end{array}$ & $\begin{array}{c}\text { Special } \\
\text { vocabulary }\end{array}$ & $\begin{array}{l}\text { Special } \\
\text { behaviours and } \\
\text { reactions }\end{array}$ & $\begin{array}{l}\text { Surprising } \\
\text { results, leading } \\
\text { to conclusions } \\
\text { other than } \\
\text { expected } \\
\end{array}$ \\
\hline $\begin{array}{l}\text { Opening ques- } \\
\text { tions }\end{array}$ & $\begin{array}{l}\text { Answers empha- } \\
\text { sised the variety } \\
\text { of matters that } \\
\text { councillors take } \\
\text { an interest in }\end{array}$ & $n / a$ & $\begin{array}{l}\text { One councillor } \\
\text { excused himself } \\
\text { from the sur- } \\
\text { vey, stating that } \\
\text { he first want- } \\
\text { ed to learn more } \\
\text { about the Nation- } \\
\text { al Science Cen- } \\
\text { tre's project }\end{array}$ & $\begin{array}{l}\text { Councillors avoid- } \\
\text { ed being reached, } \\
\text { as they were un- } \\
\text { certain about the } \\
\text { character of the } \\
\text { survey. Many } \\
\text { of them were sus- } \\
\text { picious about its } \\
\text { purpose and the } \\
\text { use of its findings }\end{array}$ \\
\hline $\begin{array}{l}\text { Specific and } \\
\text { deepening ques- } \\
\text { tions }\end{array}$ & \begin{tabular}{|l|} 
Councillors gave \\
very different an- \\
swers to specific \\
questions; even \\
so, the answers \\
proved instru- \\
mental in estab- \\
lishing which \\
questions and \\
notions the coun- \\
cillors did not un- \\
derstand. They \\
also revealed pos- \\
itive correlations \\
between a coun- \\
cillor's knowl- \\
edge of municipal \\
finances and their \\
function on the \\
council and its \\
commissions
\end{tabular} & $\begin{array}{l}\text { The use of spe- } \\
\text { cial vocabulary } \\
\text { by councillors } \\
\text { was not identi- } \\
\text { fied during the } \\
\text { interviews, but } \\
\text { demending at- } \\
\text { titudes towards } \\
\text { the government } \\
\text { and unwillingness } \\
\text { to assume fis- } \\
\text { cal responsibility } \\
\text { were noticeable }\end{array}$ & $\begin{array}{l}\text { Councillors avoid- } \\
\text { ed giving direct } \\
\text { answers, part- } \\
\text { ly because they } \\
\text { did not have the } \\
\text { necessary spe- } \\
\text { cific knowledge, } \\
\text { and partly due } \\
\text { to their unwilling- } \\
\text { ness to discuss } \\
\text { "touchy" matters, } \\
\text { e.g., tax increas- } \\
\text { es. Such behav- } \\
\text { iours were shown } \\
\text { by most coun- } \\
\text { cillors }\end{array}$ & $\begin{array}{l}\text { Councillors were } \\
\text { found to have } \\
\text { a very limited ac- } \\
\text { ademic knowl- } \\
\text { edge of the local } \\
\text { government fi- } \\
\text { nancing system, } \\
\text { so asking the } \\
\text { deepening ques- } \\
\text { tions was point- } \\
\text { less; also, their } \\
\text { tendency to avoid } \\
\text { answering ques- } \\
\text { tions obstructed } \\
\text { the in-depth in- } \\
\text { terviews }\end{array}$ \\
\hline $\begin{array}{l}\text { Final and sum- } \\
\text { ming-up ques- } \\
\text { tions }\end{array}$ & $\begin{array}{l}\text { The end part } \\
\text { of the interviews } \\
\text { was used to probe } \\
\text { matters that the } \\
\text { respondents } \\
\text { omitted before }\end{array}$ & $\begin{array}{l}\text { Rather than talk- } \\
\text { ing about vital } \\
\text { matters, coun- } \\
\text { cillors made ref- } \\
\text { erences to the } \\
\text { majority politi- } \\
\text { cal party on the } \\
\text { council, the } \\
\text { so-called "them" }\end{array}$ & $\begin{array}{l}\text { As well as avoid- } \\
\text { ing giving direct } \\
\text { answers, some } \\
\text { councillors tend- } \\
\text { ed to discuss mat- } \\
\text { ters unrelated } \\
\text { to the question } \\
\text { they were asked }\end{array}$ & $\begin{array}{l}\text { Irrational at- } \\
\text { titudes, some } \\
\text { councillors re- } \\
\text { fused to partici- } \\
\text { pate in the survey } \\
\text { without stating } \\
\text { any reason for } \\
\text { their decision }\end{array}$ \\
\hline
\end{tabular}

Source: compiled by the author from interview data. 


\section{Current lines of research on fiscal illusion and its new aspects}

A review of studies on fiscal illusion, both classical and more recent, shows that most of them used the quantitative approach. While it is quite understandable in economic sciences, it also leaves a feeling of something being amiss considering the increasing role of behavioural finance, fiscal sociology, and the psycho-political determinants of economic decisions. In this situation, the introduction of the qualitative and comparative methods as the enhancement of the quantitative approach is necessary. The most appropriate methodology combines comparative and complementary methods (quantitative and qualitative tools).

Among the large-scale comparative studies on fiscal illusion, there is the study by Mourão (2008), which resulted in the creation of a fiscal index and a benchmark for democratic countries. The study used a group of 68 countries for which data on public finance transparency, etc., were available after 1960, and they examined 17 dimensions of fiscal illusion that were assigned specific variables. The study found that the degree of fiscal illusion in the selected countries was high and that it started to fall in many of them around the mid-1980s. Poland's score on the fiscal illusion index, which was scaled from 0.01 (low illusion) to 0.99 (high illusion), fell between 1960 and 2006, from 0.986 to 0.767 , placing her among countries with the highest levels of fiscal illusion such as Russia, Pakistan, Guatemala, and Honduras. The leader of the ranking was Sri Lanka, while Germany, Canada, Austria, New Zealand, the Netherlands, and Sweden were at the bottom.

In 2011, Dell'Anno and Dollery constructed a fiscal illusion index for the EU member states in the macroeconomic framework using a quantitative approach and a structural equation perspective. According to their findings, the main factors that encourage the deployment of fiscal illusion strategies were the share of self-employment in total employment, the educational level of citizens, and the size of the tax burden (Dell'Anno and Dollery 2014, pp. 937-960). They also found that policy-makers attempted to 'conceal' the real tax burden by means of debt illusion, fiscal drag, wage withholding taxes, and taxes on labour. In this study, too, Poland was assigned to the group of countries with the highest average level of fiscal illusion (Romania, Cyprus, Greece, Italy, Belgium, and Bulgaria).

The combination of quantitative and qualitative methods is a characteristic feature of studies on the Swedish tax system and the current situation in Romania. Nuţă and Nuţă (2018, pp. 78-83) brought to attention the qualitative aspects of fiscal illusion and consequently proposed considering the phenomenon in the fiscal sociology framework that, in their opinion, helped capture complex socio-economic relations between citizens and the State, during which both parties adopt roles and attitudes revealing fiscal illusions. The creation of the concept of fiscal sociology and the 'fatherhood' of this discipline is credited to a prominent Austrian economist, Joseph Schumpeter. He was among the first to notice strong associations between the determinants and 
consequences of tax systems and all public authority and social structure policies, the institutional organisation of the state, a country's political system, culture, and history, and national traits (Campbell 1993, pp. 163-185). The fiscal sociology framework gives a convincing argument for considering fiscal illusions from a broader perspective, i.e., one including its social, sociological, cultural, and political aspects. The qualitative component of the Polish study has demonstrated that the mentality of the public and individuals should also be taken into account.

A combination of qualitative and quantitative methods, which I would advocate myself, was used by researchers studying the Swedish tax system (Sanandaji and Wallace 2010, pp. 1-11). The study was carried out by a private polling institute in the spring of 2003 with a sample of around 1000 randomly selected Swedish adults as part of a weekly phone survey. The probability of fiscal illusions occurring in Sweden is considerable because it is one of the countries with high tax rates and a large number of indirect taxes. The study showed that tax illusions may have more sources than tax invisibility alone. A person may be aware of the existence and size of a particular tax, and yet fail to recognise the incidence of its burden and thereby underestimate the total individual tax burden. The Swedish survey respondents correctly assessed the size of payroll taxes, but most of them misplaced the tax burden. Sanandaji and Wallace described a complex tax situation in which the incidence of income taxes is intentionally concealed as "fiscal obfuscation."

Abatemarco and Dell'Anno (2020, pp. 246-273) considered the problem of progressive taxation with respect to fiscal illusion and cognitive anomalies. Using econometric analysis, they validated the impact of fiscal illusion on tax progressivity in the framework of retrospective voting models and rent maximisation. Their study showed that the tax system is more (less) progressive when taxes and public expenditures are perceived less (more) and that an increase in the median voter's income may positively or negatively affect tax progressivity, depending on whether fiscal illusion is pessimistic or optimistic. Some new and very interesting aspects of fiscal illusion have recently been brought to attention in the Buehn, Dell'Anno, and Schneider (2018, pp. 1609-1630) analysis of interactions between fiscal illusion and the shadow economy. Concealing the real tax burden, they found that an increase of taxation entailed increases in shadow economic activities and fiscal illusion. Having assumed that fiscal illusion and the shadow economy were interrelated, and using a sample of 104 developed and developing countries, they demonstrated that a higher tax burden stimulated the shadow economy and indirectly incentivised the government to increase the level of fiscal illusion. A simultaneous analysis of the two latent variables (the shadow economy and fiscal illusion) for the first time indicated that the shadow economy may have a positive effect on fiscal illusion and that fiscal illusion may negatively affect the shadow economy.

A new and very interesting perspective on fiscal illusion can be found in Baekgaard, Serritzlew, and Blom-Hansen (2016, pp. 26-44). They observed that fiscal illusion is traditionally attributed to imperfect information, which inhibits the correct assessment of the costs and benefits of actions taken by public authorities and of the services they deliver. The the- 
oretical, experimental model they built assumes that fiscal illusion may have more causes than limited access to information, incomprehension, or fiscal or political ignorance. They called it "an attention model" because it considers a lack of attention as one of the sources of fiscal illusion, attributing the emergence of fiscal illusion to attention effects rather than information effects. A plausibility test carried out using experimental methods produced evidence in favour of a hypothesis derived from the attention model of fiscal illusion while rejecting hypotheses derived from the standard argument. As a result, Baekgaard, Serritzlew, and Blom-Hansen concluded that the traditional assumption pointing to incomplete information as the force driving fiscal illusion was likely to be wrong. The weight they gave to the complexity of fiscal illusion and the specificity of its context makes their approach similar to the one proposed within the fiscal sociology framework.

Another interesting line of research is the study of factors that influence politicians' decisions that have some bearing on the private sector. The dominant view in this research is that politicians calculate the political costs and benefits of their decisions (Levinson 2000 pp. 345-350; 2005 p. 915; Chang 2009, pp. 541-584), because public authorities handle various costs differently than private market entities. The possibility of public-private cooperation being a source of additional fiscal illusions and higher financial costs has been recently noticed by Cepparulo, Eusepi, and Giuriato (2019). The limited transparency of public-private projects can be a source of many unforeseen financial risks and illusions. In Poland, the concept of public-private partnership is slowly being embraced, although it is frequently met with deep scepticism.

Both recent studies on fiscal illusion and those conducted in past decades are predominantly quantitative in methodology. In economic sciences, the approach is frequently necessitated by the requirement to use formalised research tools. Unfortunately, the omission of the qualitative aspects of fiscal illusion deprives its picture of vital elements and leads to results that are either inconclusive or conflicting.

The wealth of studies on fiscal illusion testifies not only to the importance and complexity of the phenomenon, but also the variety of approaches that are used to define, attribute, and quantify the phenomenon. An illustration of how complex it is might be the fact that even the quantitative research recognises as fundamental the quality of a country's democratic institutions, the level of population education, and other qualitative factors.

One of the most desirable and promising lines of research into fiscal illusions surrounding local government finances in Poland focuses on the 'flypaper effect'. This phenomenon means that local self-governments spend more when the source of their budget funding is intergovernmental transfers than when it is locally raised revenue (local taxes and fees). In the literature, the phenomenon is commonly called the flypaper effect to indicate that 'money sticks where it hits' (Gramlich 1977, p. 219; Gamkhar and Oates 1996, p. 501-511; Rosen 1999, p. 502). It is also referred to as an anomaly, with the tendency to spend a higher fraction of general and unrestricted grants than the income of local taxpayers (Hamilton 1983, p. 347).

Local property taxes and general grants are important sources of revenues for local self-governments, but what is most important is how local tax rates and grant formulas 
are determined in practice. These solutions are fundamental for local fiscal discipline and local government performance (Dollery et al. 2020, pp. 39-225). Different types of tax autonomy (tax separation versus tax base sharing) and its impact on local spending were empirically examined by Liberati and Sacchi (2013, pp. 183-205). A direct link between fiscal illusion and the flypaper effect was indicated in the works of authors such as Julio López-Laborda and Antoni Zabalza (2012), and Hendra Kusuma (2017). A study on one of the German Länder has shown that general grants contribute to higher budget spending rather than cuts in local taxes (Langer and Korzhenevych 2018, pp. 1-36). Earlier studies, too, pointed to links between fiscal illusion and the flypaper effect. Among the various hypotheses used by researchers to empirically verify and evaluate fiscal illusion, Dollery and Worthington (1996) indicated the complexity of public revenue systems, public revenue flexibility, renter illusion, debt illusion, and, last but not least, the flypaper effect. As the reforms of intergovernmental transfers and property taxation systems can be taken advantage of by bureaucrats and local politicians to advance their own agendas, rent seeking is unlikely to be the cause of the flypaper effect in the Netherlands (Allers and Vermeulen 2016, pp. 115-129).

Fiscal illusions are a special problem for Central and Eastern European countries perceived as 'young democracies', which have launched fundamental reforms and processes to decentralise public finances. To the best of the author's knowledge, no studies have been undertaken to analyse the fiscal illusion problem in these countries in the context of local government funding sources. The problem does not go unnoticed, however. It is indirectly studied in terms of decentralisation efforts, public finance reforms, the distribution of revenues, and fiscal consolidation of the public sector (Dillinger 2007, pp. 7-9). In countries such as Bulgaria, Romania, Latvia, and the Czech Republic, public sectors have undergone a steady increase in financial decentralisation. After first attempts to assign expenditures and revenues among government levels in the early 1990s, financial self-governance began to strengthen during the subsequent decades, with a tax and revenue reform that abrogated sharing arrangements and in many cases allowed municipal councils to exercise some discretion over certain local taxes.

In some countries the reverse process took place, the legislative basis increased the share in state taxes (more than common taxes), but common taxes have been formally treated as "own" revenues. Unfortunately, many municipalities in Central-Eastern Europe did not enjoy tax autonomy at the beginning of the new millennium; but then, an action plan on fiscal decentralisation endowed many of them with a purely local taxes structure, mainly real estate tax, all kinds of property taxes, and shared taxes.

Regrettably, in many countries, fiscal decentralisation is uneven and asymmetric. In the Czech Republic, the taxing autonomy of municipalities is marginal despite the significant level of local revenues, while in Estonia, municipalities are highly dependent upon various transfers from the central government (Geisler, Hammerschmid, and Raffer 2019, pp. 30, 41, 70, 122). In the context of my considerations, one characteristic of decentralisation in Slovenia seems to be very meaningful: "Local share in revenue and spending is below the EU average. In theory, local taxes fund an essential part 
of local budgets, so transfers and taxes are about even. In practice, the state regulates and collects most of them. The largest source of tax revenue is the municipal share of personal income tax (PIT), whereof a share is used for fiscal equalisation. The only tax local authorities can set the rate on is property tax. In contrast to revenue, local autonomy in spending is rather high" (Rakar and Klun 2019, p. 181). This situation is described as a straight path to fiscal illusion in intergovernmental fiscal relations.

A special case is that of Hungary, where limited decentralisation and the politicisation of local governments make "decentralisation counter-productive since it does not allow the advantages that the normative economic approach applies to prevail” (Vigvári 2020, p. 2). Similarly, the limited fiscal decentralisation and uneven progress of the participatory democracy in Romania can create and consolidate fiscal illusions (Alexandru 2018).

\section{Conclusion}

The study of Polish councillors has determined that the most probable factor that forms their attitudes and views is the inappropriate design of the local government funding system. Because it is essentially based on intergovernmental transfers, local authorities do not feel the need to assume fiscal responsibility. It has also been found that councillors in Poland have limited academic knowledge of how the system works and according to what rules local governments are financed. The reasons for the high level of fiscal illusion in the Polish system, other than the superficial financial knowledge and imperfect information, can also be what Baekgaard, Serritzlew Blom-Hansen (2016) have called "a lack of attention", as well as unawareness or absence of reflection on where intergovernmental transfers come from and who pays income taxes shared between cities.

The central government's traditional control of public finances in Poland also contributes to low fiscal and financial responsibility among local governments. It is not a specifically Polish problem, because its implications for the practice of decentralisation are noticeable in many other countries too. It essentially involves the devolution of public services (and their costs) to lower levels of government without appropriate devolvement of public revenues. Local governments are then faced with the problem of financing the increasing number of costly public services that are delegated to them because the fiscal efficiency of local taxes is low. Yet another problem is the limited fiscal autonomy of the lower levels of government in unitary countries, which arises from the need to ensure the uniformity of the tax system.

All of these circumstances lead to the establishment of local government funding systems that combine traditional general and specific grants with a significant proportion of various revenue sources, shared taxes, or tax supplements. Many national taxes are fiscally efficient, so having a share of them is advantageous for municipalities, but it may also lead to ingraining fiscal illusions in attitudes and mentality. It also breaks the direct relationship between costs (understood as the level of municipal taxes) and the range and quality of local public goods (represented by the level of expenditures). 
Moreover, when the majority of municipal expenditures are not funded from local taxes, fees, and charges, local politicians have no direct fiscal responsibility towards the community. Fiscal illusions definitely have negative consequences that include the underfunding and limited range of public services, as well as poor civic participation and weak public control. The basis of rational local government funding system is the direct responsibility of local politicians for the financial and fiscal decisions they make, as well as respect for the choices of local communities and public choice theory.

The above indicates that the Polish legislation on local government funding should be amended by increasing the amount of local revenues (taxes, fees and charges) while reducing the proportion of intergovernmental transfers (grants and shared taxes). Given the high level of fiscal illusion among local authorities and their weak political will to assume greater fiscal responsibility, the amendments should aim to change the existing systemic and legislative solutions. The conclusions from the study are very important for Central and Eastern European countries in creating local government funding systems, as well as for countries aspiring to join the EU, which will undertake the decentralisation and democratisation of their state structures in the future. Of special importance is the need to avoid asymmetric decentralisation, i.e. where services and expenditures are devolved to lower levels of government without providing them with an appropriate share of public revenues and the rationality of transferring part of fiscal responsibility to local authorities.

\section{References}

Abatemarco, A., Dell'Anno, R. (2020), Fiscal illusion and progressive taxation with retrospective voting, "Economic And Political Studies", 8 (2), pp. 246-273, https://doi .org/10.1080/20954816.2020.1728831

Ahmad, E., Brosio, G. (eds.) (2015), Handbook of multilevel finance, Edward Elgar Publishing, Cheltencham, https://doi.org/10.4337/9780857932297

Akin, Z., Bulut-Cevik, Z., Neyapti, B. (2016), Does Fiscal Decentralization Promote Fiscal Discipline?, "Emerging Markets Finance \& Trade”, 52 (3), pp. 690-705, https:// doi.org/10.1080/1540496X.2015.1012920

Alexandru, D.G. (2018), Uneven Progress of the Participatory Democracy in Romania, "Acta Universitatis Lucian Blaga", 146, Iurisprudentia, Sibiu.

Allers, M.A., Vermeulen, W. (2016), Capitalization of equalizing grants and the flypaper effect, "Regional Science and Urban Economics", 58, pp. 115-129, https://doi.org/10 .1016/j.regsciurbeco.2016.03.005

Baekgaard, M., Serritzlew, S., Blom-Hansen, J. (2016), Causes of Fiscal Illusion: Lack of Information or Lack of Attention?, "Public Budgeting \& Finance", 36 (2), pp. 26-44, https://doi.org/10.1111/pbaf.12091

Buchanan, J.M. (1997), Finanse publiczne $w$ warunkach demokracji, Wydawnictwo Naukowe PWN, Warszawa. 
Buehn, A., Dell'Anno, R., Schneider, F. (2018), Exploring the dark side of tax policy: an analysis of the interactions between fiscal illusion and the shadow economy, "Empir Econ”, 54, pp. 1609-1630, https://doi.org/10.1007/s00181-017-1277-7

Campbell, J.L. (1993), The State And The Fiscal Sociology, "Annual Review of Sociology”, 19, pp. 163-185, https://doi.org/10.1146/annurev.so.19.080193.001115

Cepparulo, A., Eusepi, G., Giuriato, L. (2019), Public-Private Partnership and fiscal illusion: A systematic review, "Journal of Infrastructure, Policy and Development", 3 (2), pp. 288-309, https://www.academia.edu/41249948/PublicPrivate_Partnership _and_fiscal_illusion_A_systematic_review (accessed: 23.06.2020).

Chang, Y. (2009), Empire Building and Fiscal Illusion? An Empirical Study of Government Official Behaviours in Takings, "Journal of Empirical Legal Studies", 6 (3), pp. 541-584, https://doi.org/10.1111/j.1740-1461.2009.01153.x

Dell'Anno, R., Dollery, B.E. (2014), Comparative fiscal illusion: a fiscal illusion index for the European Union, "Empir Econ”, 46, pp. 937-960, https://doi.org/10.1007/ s00181-013-0701-x

Dillinger, W. (2007), Intergovernmental Fiscal Relations in the New EU Member States, Consolidating Reforms, "World Bank Working Paper" No. 111, Washington, https:// doi.org/10.1596/978-0-8213-7147-3

Dollery, B., Worthington, A. (1996), The Empirical Analysis of Fiscal Illusion, "Journal of Economics Surveys", 10 (3), pp. 261-297, https://doi.org/10.1111/j.1467 -6419.1996.tb00014.x

Dollery, B., Kitchen, H., McMillan, M., Shah, A. (2020), Local Public, Fiscal and Financial Governance. An International Perspective, Palgrave Macmillan, Springer Nature Switzerland AG, Cham, https://doi.org/10.1007/978-3-030-36725-1

Gamkhar, S., Oates, W. (1996), Asymmetries in the response to increases and decreases in intergovernmental grants: Some empirical findings, "National Tax Journal", 49 (4), pp. 501-512, https://doi.org/10.1086/NTJ41789223

Geisler, R., Hammerschmid, G., Raffer, Ch. (eds.) (2019), Local Public Finance in Europe. Country Reports, Bertelsmann Stiftung, Gütersloh.

Gemmell, N., Morrissey, O., Pinar, A., (2002), Fiscal illusion and political accountability: Theory and evidence from two local tax regimes in Britain, "Public Choice", 110 (3/4), pp. 199-224, https://doi.org/10.1023/A:1013015330173

Gordon, N. (2004), Do Federal Grants Boots School Spending? Evidence from Title I, “Journal of Public Economics", 88 (9-10), pp. 1771-1792, https://doi.org/10.1016/j.jp ubeco.2003.09.002

Gramlich, E.M. (1977), Intergovernmental grants: A review of the empirical literature, [in:] W.E. Oates (ed.), The political economy of fiscal federalism, Heath, Lexington.

Guziejewska, B. (2016a), Rodzaje i zakres iluzji fiskalnych wśród polskich radnych w świetle wyników badań jakościowych, "Samorząd Terytorialny", 3, pp. 58-67.

Guziejewska, B. (2016b), Fiscal Illusions in Local Self-Government Finance. Complementarity of Qualitative and Quantitative Methods, "Journal of US-China Public Administration”, 13 (7), pp. 483-489, https://doi.org/10.17265/1548-6591/2016.07.006

Hamilton, B.W. (1983), The flypaper effect and other anomalies, "Journal of Public Economics” 22 (3), pp. 347-361, https://doi.org/10.1016/0047-2727(83)90040-3 
Irwin, T.C. (2016), Dispelling fiscal illusions: how much progress have governments made in getting assets and liabilities on balance sheet?, "Public Money \& Management", 36 (3), pp. 219-226, https://doi.org/10.1080/09540962.2016.1133981

Kusuma, H. (2017), Flypaper Effect: Fiscal Illusion and Bureaucratic Model, "Jurnal Ekonomi dan Studi Pembangunan”, 9 (1), pp. 28-40, https://doi.org/10.17977/um 002v9i12017p027

Langer, S., Korzhenevych, A. (2018), Equalization transfers and the pattern of municipal spending: An investigation of the flypaper effect in Germany, "CEPIE Working Paper”, No. 01/18, Technische Universität Dresden, Center of Public and International Economics (CEPIE), Dresden, http://nbn-resolving.de/urn:nbn:de:bsz:14-qu cosa-234984 (accessed: 25.06.2020).

Levinson, D.J. (2000), Making Government Pay: Markets, Politics, and the Allocation of Constitutional Costs, "University of Chicago Law Review", 67 (2), pp. 345-420, https://doi.org/10.2307/1600491

Levinson, D.J. (2005), Empire-Building Government in Constitutional Law, "Harvard Law Review", 118 (3), pp. 915-972.

Liberati, P., Sacchi, A. (2013), Tax decentralization and local government size, "Public Choice”, 157 (1), pp. 183-205, https://doi.org/10.1007/s11127-012-9937-9

López-Laborda, J., Zabalza, A. (2012), Intergovernmental Fiscal Relations: the Efficiency Effect of Taxes, Transfers and Fiscal Illusion, International Center for Public Policy Working Paper 12-29, International Center for Public Policy Andrew Young School of Policy Studies Georgia State University, Atlanta.

Mourão, P.M. (2008), Towards a Fiscal Illusion Index, “MPRA Paper” 9760, University Library of Munich, Munich.

Mueller, D.C. (2003), Public Choice III , Cambridge University Press, Cambridge, https://doi.org/10.1017/CBO9780511813771

Nuţă, A., Nuţă, F. (2018), Fiscal Illusion - An Actual Perspective, Journal of Public Administration, "Finance and Law", 13, pp. 78-83.

Oates, W.E. (1972), Fiscal Federalism, Harcourt Brace Jovanovich, New York.

Oates, W.E. (1979), Lump-sum Intergovernmental Grants Have Price Effects, [in:] P. Mieszkowski, W. Oakland (eds.), Fiscal Federalism and Grants-in-aid, The Urban Institute, Washington, pp. 23-30.

Oates, W.E. (1998), On the Nature and Measurement of Fiscal Illusion: A Survey, [in:] G. Brennan et al., Taxation and Fiscal Federalism: Essays in Honour of Russell Mathews, Australian National University Press, Sydney, pp. 65-82.

Rakar, I., Klun, M. (2019), Slovenia, Part 8, [in:] R. Geisler, G. Hammerschmid, Ch. Raffer (eds.), Local Public Finance in Europe. Country Reports, Bertelsmann Stiftung, Gütersloh, pp. 181-191.

Rosen, H.S. (1999), Public Finance, Fifth Edition, Irwin/Mc Graw-Hill.

Sanandaji, T., Wallace, B. (2010), Fiscal Illusion and Fiscal Obfuscation: An Empirical Study of Tax Perception in Sweden, "Working Paper Series" 837, Research Institute of Industrial Economics, https://doi.org/10.2139/ssrn.1619268

Vigvári, A. (2020), Lost Illusions: Fiscal Decentralization in Hungary, https://english .sim.dk/media/14243/andras-vigvari.pdf (accessed: 25.08.2020). 


\section{Iluzje fiskalne w ujęciu porównawczym: synteza wyników badań w Polsce na tle nowych podejść i badań empirycznych wybranych krajów}

Przedmiotem artykułu są iluzje fiskalne w zdecentralizowanych systemach finansów publicznych. Pojawienie się bowiem w systemie niezależnego i autonomicznego ogniwa jakim są finanse samorządu terytorialnego powoduje nowe problemy. W artykule przedstawiono syntezę wyników badan empirycznych poświęconych rodzajom i zakresowi iluzji fiskalnych wśród polskich radnych, w której główny nacisk położono na aspekty jakościowe analizowanego zjawiska. Wnioski z badań poświęconych Polsce skonfrontowano z nowymi nurtami badań oraz nowym spojrzeniem na problem, które ukazały się w ostatnich latach. Celem artykułu jest usystematyzowanie dotychczasowego stanu wiedzy w kontekście wybranych badań empirycznych, sformułowanie postulatów dla praktyki i decydentów publicznych oraz wskazanie na kierunki pożądanych badań w przyszłości. W artykule wykorzystano metodę desk research oraz doświadczenia i subiektywne spojrzenie badawcze nabyte w toku realizacji projektu poświęconego iluzjom fiskalnym. W trakcie tych badań potwierdzono główną tezę, że system finansowania samorządu terytorialnego oparty na dochodach o charakterze transferów z budżetu państwa wpływa na powstawanie i utrwalanie iluzji fiskalnych.

Słowa kluczowe: decentralizacja fiskalna, iluzje fiskalne, relacje fiskalne państwo-samorząd, podatki lokalne 